\title{
WHERE IS WISDOM TO BE FOUND - NOW THAT WE HAVE STOPPED LOOKING FOR IT?
}

\author{
Douglas Lawrie \\ University of the Western Cape
}

\begin{abstract}
Ancient scribal culture had two faces. After arduous and largely impractical training, scribes were admitted to an elite circle and became custodians of a cultural tradition. But scribal teachers were also credited with opening the eyes of their students and 'forming humanity' in them. Scribal writers created and challenged tradition. Both faces are still evident in modern 'scribal culture'. Nietzsche, who occupies an ambiguous position in this regard, is used to illuminate aspects of tension between the two 'faces', which, given the world situation, seems relevant to the future of the academic enterprise. Finally, it is suggested that ancient wisdom still has something to tell us about these matters. The article is dedicated to Hendrik Bosman in view of his abiding interest in scribal culture, wisdom literature and יראת יהוה.
\end{abstract}

Key Words: Nietzsche; Scribes; Wisdom; Literacy; Elitism

\section{The old Fogies' Lament}

"Things fall apart; the centre cannot hold." Even before Yeats provided these words, this has been the old fogies' lament. Recently many who are not old and do not consider themselves fogies have joined the chorus. Some of these are academics who had previously shown no great attachment to the centre. The margins looked attractive when they did not harbour ISIS and the Taliban; post-truth sounded liberating when Donald Trump was not its prophet; local petit recits were charming until they revealed themselves as smallminded and xenophobic.

One could argue that the current rough beasts were born of the ill-advised liaisons of academics. Have we not posted truth to parts unknown long before 'post-truth' became word of the year for 2016? I first met 'alternative facts' as 'transgressive data' in an academic paper (St Pierre 1996). Academics 'naturalized' violence, partly by identifying violent elements in all our practices, partly by the violence of their own rhetoric. Having theoretically reduced everything to power, they are practically powerless in the face of Realpolitiker who do not give a fig for theory. Is it dissimulation when Trump says that nobody respects women more than he does or Jacob Zuma that he has done nothing wrong? In a world of simulacra and competing perspectives it is hard to say - and harder still to say why it matters. (Hint: any distinction would presuppose 'centred subjects'.)

Is Trump Nietzsche come home to roost? Since 2016, 'Nietzsche - Trump' articles and blogs have proliferated, with noted Nietzsche scholars leaping to his defence. ${ }^{1}$ Nietzsche has been misread; his strident sayings were not intended to be taken literally; he would have hated Trump. All true (true?) to be sure, but not unproblematic. Is there a correct way of reading, an understanding beyond the play of perspectives? Do authorial intentions matter and how are they determined? If Trump is a parody of Nietzsche (Schacht 2016) and if they both "revolt against the establishment and against the ruling majority's ethos" (Golomb 2017), we have to provide criteria for saying that "they have nothing in common" 
(Golomb 2017). The ones listed by Golomb (in two columns) are shaky. Perhaps Nietzsche stood for (for instance): "spontaneous, direct and impulsive action"; "sensualism and acceptance of one's inclinations"; "the ability to accept contradictions [also from yourself]". Is this not also Trump? "Power for Nietzsche is the name of the game" (Schacht 2016) - as it is for Trump.

Yet Nietzscheans will not mistake symptoms for causes. Though the purveyors of 'theory' have much to answer for - their stylistic atrocities to start with - they have little clout outside universities. If, following Marx, we consider the mode of production before the ideological products, it is obvious that academia has long pandered to late capitalism, which prizes decentred (dehumanized) subjects (human resources), signifiers without a fixed signified (\$) and states of flux (laissez faire). 'Subversive' theorizing and moralistic activism are firmly checked by a managerial system of incentives, outputs, ratings, and the like.

"Surely some revelation is at hand." In such times prophets appear early and late, "though I sent them not", lamentations abound and even the apocalyptic note crops up. Academics are probably not the best exponents of these modes. As scribes, heirs to an old scribal culture, they are better advised to try their hand at being wisdom teachers. Wisdom, a plodder rather than a superhero, has never saved or revolutionized the world. She is fragile and limited and, since she seldom appears in modish clothes, not invariably welcome at intellectual galas. ${ }^{2}$ She is apt to say embarrassing things about יראת יהוה and politically incorrect ones about fools. But are we not "lovers of wisdom" nonetheless?

In examining the relationship between the ancient scribal wisdom tradition and the modern one, I take Nietzsche along - as a shadow, not an adjudicator. Perhaps he did, as he thought, stand at the crossroads in Western thought, where our judgements can lead in several directions. Only some lead us to Trump and similar figures; only some lead to the apotheosis of Nietzsche. But Nietzsche, with all his ambiguities, is bracing company.

\section{The Two Faces of the Scribe}

The picture Carr paints of Mesopotamian scribal training, particularly the initial part, is hardly pleasant. It involved much memorizing of standard texts and lists (2005:23-29), some in Sumerian when Sumerian had long disappeared as a spoken language, other in an antiquated form of Akkadian (30). This "enforced learning of archaic material" with "huge amounts of impractical information" made the scribe "an obedient part of the broader community" (32), but also admitted him (rarely her) ${ }^{3}$ to an elite class (33). Although "the most successful scribes" created new texts $(32,36)$, the majority reproduced or edited traditional material (33ff). As Van der Toorn (2007:56) says, "the emphasis lay on memorization and scribal skills rather than on the intellectual grasp of the subject matter".

Arguably Carr underplays the other side to the picture. He quotes the following tribute of a student to his teacher: "You have opened my eyes as though I were a puppy; you have formed humanity within me" (2005:31). The images of the opening of eyes and of becoming human also appear elsewhere. Certainly, young students are inducted into a cultural tradition and an elite class, but they also enter a broad world of learning that transcends mere snobbery. They become "not merely penmen and copyists but intellectuals", "the academics of their time" (Van der Toorn 2007b:57). The few who pass through the advanced part of the curriculum become "scribes in the fullest sense of the term: scribes, scholars, and sages - the living repositories of the stream of tradition" (Van der Toorn 2007b:59). 
They become bearers but also creators of tradition. The Gilgamesh Epic, part of the ancient curriculum, is still part of the curriculum in many Humanities courses - with good reason. Job (in its present form) and Ecclesiastes both bear the stamp of scribal culture, ${ }^{4}$ neither simply repeats received wisdom. Did the Dialogue of Pessimism do so? Those whose eyes have been opened often see more than their teachers showed them - or wanted them to see.

Apparently our scribes (sages?) still wear both these faces. Carr (2005:33) cites historians of education who "have long supposed that the highest levels of education are often marked by their distance from the practical, isolating a small group of those who can afford specialization and irrelevance from the mass of those relegated to "vocational' ... training". They still distinguish themselves through "virtuosity in mastering of an arcane writing system". Can this refer to our universities, our 'engaged academics'? Bearers of a cultural tradition, we producers of knowledge, we free spirits? But we have been disciplined into our disciplines and need to be aware of current discourses - that is, fashions. Elitists? Not unless interlopers venture to express uninformed opinions about the king's absence of clothes.

Initially scribes had a high status simply because theirs was a scarce skill that ensured its possessors good careers. In Mesopotamia the ummia, the scribal teacher, was an exalted figure, being close to both the kings and the god of wisdom, Enki/Ea. ${ }^{5}$ As literacy spread, not all scribes could attain high posts: further education became necessary. ${ }^{6}$ The status of teachers also fell. In Greece they had no particular standing; in Rome they were sometimes slaves (Harris 1989:160). Already in Mesopotamia royals and nobles boasted of their scribal skills (Van der Toorn 2007b:54f). No prominent citizen in Greece and Rome wanted to be an agrammatos or illiterates. ${ }^{7}$ The precious art was in danger of becoming all too common.

As Van der Toorn (2007a; 2007b:65f) points out, the scribal art changed from being a difficult skill to being an arcane art. Initially scribal education conferred social standing; later social standing was almost a prerequisite for scribal education. Scholarly works had to be kept from outsiders, suggesting that they were not that hard to master. Being unable to reproduce elitism in that form, we take our refuge in disciplinary totems and taboos, mainly linguistic ones. 'Academic literacy' is the current term for Carr's 'arcane writing system'.

Those who cherish the other face of scribal culture will find Nietzsche an unreliable ally. He fulminates often against the barrenness of scholarship ${ }^{8}$ and the ponderous style of academic writing (GS 366). The ideal practitioner of the gay science moves on dancing feet and wields a hammer. Whereas the old scribe was enlisted to confirm and reproduce the old world and the old humanity, the new one has to create and destroy, to destroy in order to create. Nietzsche himself makes the distinction between those whose task (not an ignoble one) it is to make the past "übersichlich, überdenkbar, faszlich, handlich" the true philosophers who say "So soll es sein" in order to create the future". "Ihr "Erkennen' ist Schaffen" (BGE 211).

But Nietzsche can be misunderstood here. He issues no licence for the production of knowledge by fiat. Real philosophers who are "Befehlende und Gesetzgeber", must have acquired and mastered all that the mere pedants, their servants, have acquired (BGE 211). Nietzsche often criticizes scholars of his time for being too lax, too easily tempted by superficialities (D 190, 195). He might well have applauded the arduous Mesopotamian curriculum as a preliminary. Secondly, he outdoes practically everyone in his elitism ${ }^{9}$. Real education is for the very few, those who were bred for it (BGE 213) and must form a new caste. In this matter, as elsewhere, he rejects the notion of equality of rights with scorn. 
Nietzsche/Zarathustra is a curious teacher of wisdom. He appeals with great passion, but often says that that he does not want to be understood, at least not fully or by everyone. "Alles, was tief ist, liebt die Maske" (BGE 40; cf BGE 290). But as Hollingdale (1973:220) says: "Either you seek to communicate or you do not." You may seek to frustrate communication, but that does not require a profound mind. Nietzsche's claim that he wrote for a select few - and the status of the thousands who apply for the few vacancies - I leave to those who practice Nietzschean psychology. It suffices to say that Nietzsche too hid wisdom from the plebs behind a verbal curtain, albeit a remarkable richly embroidered one.

Yet we may thank Nietzsche for opening our eyes at many points without closing them to what Nietzsche did not want to see. The second face is also still with us. Awakening the humanity in others and ourselves, opening our eyes and those of others to a world beyond our own limited experience, seeing how far our reason can take us towards wisdom: these are noble tasks. Even Nietzsche does not scorn the mere "workers in philosophy", the workhorses of wisdom (BGE 211). Being sick to death of everything subjective "und seiner verfluchten Ipsissimosität", he has kind words for the objective spirit with which scholars seek, as best they can, to mirror the object of knowledge (BGE 207). ${ }^{10}$ If it enables us together - to "confront the global situation with an attitude neither local nor imperialistic" (Burke 1945:442f), few occupations can be nobler than the scribal craft of today.

For craft it is, as Nietzsche rightly saw: it may ennoble, but it does not make vornehm. ${ }^{11}$ We have other mechanisms in academia to cater for that striving. What they are and how much of our attention they occupy, I leave to my readers to ponder. Perhaps the second face of the scribe would be more visible if we were less vornehm and more noble - and vulgar. Yes, and a little less shy of the herd.

\section{Sumerian Today}

Do modern scribes have to write in 'Sumerian', a jargon accessible only to a small minority of initiates? Technical terminology can be defended on two scores: it serves precision and (often) brevity. Because folk names are hopelessly misleading, the scientific names for plants are useful to botanists - and ordinary gardeners. Wisdom, even practical wisdom, often requires precision. And when a single word or phrase carries with it an entire line of thought, insiders can dispense with much needless verbiage in speaking to other insiders.

But technical terms are not invariably chosen for their acknowledged virtues. Academics and outsiders alike have long complained about the obscurity of much academic writing; some academics have long defended it. From Russell Jacoby's depressing list of such defences (1994:164-173), some by well-known scholars, I give one example. Frederic Jameson speaks of 'repressive clarity,' 12 arguing that one does not expect molecular biology, nuclear physics, linguistics or symbolic knowledge "to be laid out with all the leisurely elegance of the coffee table magazine". Why should literary and cultural theory be less complex? Moreover, "clear and fluid journalistic writing" may serve a sinister ideological purpose, namely to 'facilitate clichés', perpetuate 'cheap facility' and avoid 'real thinking' (quoted in Jacoby 1994:167f).

Brevity suffers equally. Ankersmit (1998:220) complains of the superfluous technicalities and obscure jargon in academic writing: "The argumentative nucleus and the length of postmodern writings are often inversely proportional to each other." Without the 'superfluous technicalities', the lengthy arguments can be justified. When one explains Kant's distinction between the hypothetical and the categorical imperative to undergraduates, brevity cannot be the first consideration. The jargon, in turn, is justified if it compresses the argument. 
In an interview $^{13}$ Homi Bhabha shows how the verbiage employed can be entirely disproportionate to the sense conveyed. Roughly a page is devoted to saying that Western values, institutions and beliefs were not transplanted unchanged to India under the Raj. The time it took for orders to reach India and the different context of both those who had to implement the orders and those on whom they were enforced subtly changed the implications of the orders. Moreover, the people involved, both colonizers and colonized, had to play dual roles, belong to two worlds at once. Quite. Where is the need to say that "the whole site of the colonial edict is continually split and doubled between origination and enunciation, temporally disjunct, in a way historically time-lagged" (1993:101)? (The whole sentence runs to eight lines of print.)

The following sentence, a sin against both precision and brevity, deserves a paragraph of its own: "What I would like to do is at least indicate where other 'genealogies' of pragmatism can be constructed, for example where an other reading of Emerson can certainly be produced - one in which, say, the essay 'Experience' would be properly seen as announcing the foreclosure of that category (as the title ironically implies), the subject of 'experience' him or herself dispossessed by the materiality of signs; or, for that matter, as if in a parody of all genealogies, go back to 'father' Protagoras, whose famous dictum on the metron - that is 'Man is the measure of all things' ... and so on, often cited as a founding text (however contradictorily) of relativism, humanism and pragmatism - may be read as a performative text in which the category of 'man (anthropos)' is decentered, dismantled, and dissolved by a term, measure, which inscribes this non-subject in an activity of sheer semiosis and differencing not unlike, say, Peirce (Cohen: 1995:97). ${ }^{14}$ At least imagining Peirce as 'an activity of sheer semiosis' provides comic relief."

If the desire for precision and brevity does not explain the scribal addiction to jargon, what does? Certainly not a desire for stylistic elegance. Once mere literacy was not a secure barrier, ancient Mesopotamian scribes resorted to secrecy to keep their craft confined to insiders. Unable to copy them, modern scribes had to invent a new literacy, 'academic literacy', over which they could exercise control. As the Marxist critic Kananagh (in Girard 1989:15) ${ }^{15}$ puts it: "A given theory becomes most adequate to its own consolidation and propagation when the resolutely arduous and paradoxical nature of its discourse serves to prolong and extend the progressively more self-enclosed and self-sustaining dialogue of master and disciple as an arcane science accessible only through diligent apprenticeship." That is, scribes protect their turf.

In our world very many people are far from uneducated. Outside the university there are many, with or without postgraduate qualifications, who read widely, think deeply and are well-informed about a range of subjects. These pundits pose a threat to professional 'scribes'. To compensate for their lack in formal disciplinary background, pundits draw on their cross-disciplinary knowledge and their ability to explore angles neglected in 'the literature'. Confronted by a super-pundit like Kenneth Burke ${ }^{16}$ (for instance), the scribal centre might not hold and mere anarchy might be loosed upon academia! Dread thought.

\section{Scribal Elitism}

Our precious (in both senses) 'current discourses' and obscurantist (yes) terminology protect a scribal elite. The heroes are the profound professionals, the villains the congenitally stupid journalists. ${ }^{17}$ The crudeness and vulgarity of the elitism sometimes beggars description. Barbara Herrnstein Smith (quoted in Jacoby 1994:165) says that academic writing is "long on new, challenging ideas ... conceptual, abstract, challenging, unfamiliar". Journalists send "vivid, dramatic and familiar messages" confirming established 
ideas. In others she would surely have condemned such reckless generalizations. ${ }^{18}$ How I wish academic articles were long on new ideas, challenging or otherwise.

Stanley Fish goes further than most in his defence of what he regards simply as professionalism. Professionalism "claims for itself exclusive possession of certain skills" (1989:173): without such a claim, the profession's work would be meaningless (172). From this it follows, quite logically, that the profession sets its own standards (174). On the basis of this, he rejects 'blind submission', because a paper with his name attached will, rightly in his view, be much more likely to be accepted. As someone who "has paid [his] dues", he has "earned the benefit of the doubt". This is self-interested but not selfish: it is driven by interests that "appear to me compelling given a sense of myself as a professional ... with a stake in the future of the profession" (173).

Fish, unlike some others, writes and argues well, but his plausible case is based on dubious assumptions. Most professions claim for themselves higher levels of skill in certain areas, not 'exclusive possession'. Though I cannot match a professional chef, I cook fairly well and can enhance my skills without special professional training. Many professions set their own standards, but these are almost always co-determined by 'consumers' outside the profession. Professional standards in medicine would not survive unless they served those who need medical care. Outsiders may not know how to formulate the norms, but are the best judges of good and bad results. Literary criticism (Fish's profession) should help outsiders, if only ultimately, with their reading of literature. Though Fish makes much of the political nature of professional decisions (1989:1972), it is the politics of the enclosed circle. $^{19}$

Scribal elites have historically been good at perpetuating themselves. Hamilton (1996:200-216) reviews the factors that stabilize the views of scholarly groups, often in the face of contradictory evidence. I list only some. Having acquired a particular theory (paradigm, method), scholars are eager to see how it works in a particular case, but not to examine the initial assumptions of the theory (201), which may be wrong or simply inapplicable in the particular case. ${ }^{20}$ Scholars develop a 'trained attachment' to certain viewpoints (201f). If I had to spend so much time and effort to learn 'Sumerian' (this jargon), it must be important. The effect is heightened if the attachment is seen as a moral one. Furthermore, contrary to their self-image, scholars are generally conformists, as experiments in social psychology have shown (202f). They seldom go against the consensus in the discipline (or subsection of it).

As a social scientist, Hamilton remains wedded to the notion of evidence. If this too is discarded, as it is in much 'theory', all the other factors continue to operate, but without the possibility of outside interference. Outsiders may criticize only if they have been inducted into the mysteries - the standards set by the profession - in which case they won't criticize. But are these mysteries so deep and obscure? Hamilton (1996:11f) discusses an experiment conducted by social psychologists. A false 'Dr Fox' (actually an actor), with a fake CV, was asked to give a lecture on "mathematical game theory as applied to physical education" to highly-trained educators. The lecture was videotaped and played to other groups and three groups were asked to evaluate it. Though the content was nonsense, 'Fox', with a bit of coaching in "double-talk, neologisms, non sequiturs and contradictory statements", fooled everyone. One commented that the lecture was 'too intellectual'; another reported having read some of Dr Fox's publications. Nobody saw through the trick.

Nietzsche's elitism was quite different, if not less pernicious. The scribal elitists who quote him approvingly may find in him a deadly enemy. To write well is to think well and good writing must communicate, so that "alles Gute Gemeingut werden und den Freien 
alles freistehe". Whoever disagrees "ist ein Feind der guten Europäer, ein Feind der freien Geister" (WS 87). "Den Stil verbessern - das heiszt den Gedanken verbessern" (WS 131). Nietzsche was (usually) a fine stylist, though he said it rather too often. His ten aphorisms on style (Zur Lehre vom Stil), written to Lou Salome (cf Andreas-Salome 1894:115f), make excellent sense. Writing should be lively and based on speech (with the written equivalent of gestures). Highly abstract ideas should be approached via the sensuous. Long periodic sentences should usually be avoided.

He did believe his books were for a limited audience (EH Preface 3, III:1), but not for a professional circle of 'gelehrte Hornvieh' (EH III:1). For universities he generally had scant respect: outsiders were often quite right to despise them (SE 8). Though his fans honour him largely for demolishing all truth claims, it is not clear that he did that: Maudemarie Clark (1990) argues persuasively that, though he consistently rejects some conceptions of truth, Nietzsche in his later writings developed his own (not fully worked out) view of truth, which largely abandoned the 'perspective metaphor' (95-149). Other interpretations would render Nietzsche's claims about truth "hopelessly confused and contradictory" (1). ${ }^{21}$ At any rate, Nietzsche did not at any time tolerate sloppy writing or thinking.

\section{What would Wisdom say?}

Nietzsche wanted his philosophy to be one of experimentation (Versuch). He welcomed ideas to which he could reply "Versuchen wir's!"(GS 51). I too wish to experiment with a rather wild idea. What if, instead of constantly trying to create (קנה) wisdom, we were to attempt to acquire (קנה) it? Shall we, by way of experiment, listen to wisdom as if it mattered to us and to others, instead of 'researching' it? Perhaps this Versuch will, as Nietzsche suggests, prove to be a Versuchung, ${ }^{22}$ but, since scribal culture is two-faced, we may be traitorously loyal to our scribal craft. The suggestions I offer below, without any attempt at completeness or finality and in most cases very briefly, constitute a Probe and a probe, not a proof. They do seem to hang together, but require much further thought.

\section{A Matter of Hearing}

The view that wisdom is primarily acquired, not innate, was widely shared in the ancient world. Confucius and Aristotle are at one in this. Receptivity of traditional lore precedes critical thinking and creativity. The latter follow later - if they follow at all. That the wisdom according to the Old Testament is based on listening is a commonplace (cf Crenshaw 1998:24). Wisdom can be glossed as "a listening heart"; Woman Wisdom requires first of all to be listened to (Prov $1: 20-25 ; 8: 1-6$ ). Those qualities that are inimical to wisdom - pride (and being "wise in your own eyes"), excessive eagerness to speak, lack of self-discipline, uncontrolled emotions, drunkenness - all stand in the way of listening.

Denise Ackermann (2014:183) records (on Michael Welker' authority) what Gadamer said of Gerhard von Rad: "There was a silence in him that came out of deep listening." Perhaps that is why he took the Israelite sages seriously as interlocutors, not only as "subjects of study", ${ }^{23}$ and said of them that essentially they expounded one insight: "Constitutive for man's humanity is the faculty of hearing" (1972:314). He respected their search for what truths are available. These truths, in his account, are by no means absolutely fixed: Each saying "had its truth only in a specific sphere in life and in a specific range of comparable circumstances" $(311) .{ }^{24}$ At the same time, the "total receptivity to the truth" was not passivity, but "an intense activity" and a preparation for responding (297). 
This seems far removed from Nietzsche's ideal of "the individual who freely shapes his own character and destiny" (Golomb 2017). When Chaim Perelman (1979:131) argues that any call for change which is not backed by good reasons is arbitrary and (potentially) unjust, the status quo seems to get the inner lane. But an uncritical call for change is arbitrary; a critical one assumes that the other side has been given a hearing. Walter (2017) warns against the "absurd dream of contemporary culture that we - anyone at all - just by 'being ourselves' can surpass the ancient creativity of entire peoples". Over many centuries a few ancient scribes produced a few creative masterpieces. Today we demand of every 'scribe' to produce novelties on demand and at regular intervals.

Moreover, Nietzsche did not advocate of random creativity; nor did he think it possible. ${ }^{25}$ First, as Walter (2017) points out, his creative ideal was not for everyone. Even among scholars the majority are and should be mere hacks. Furthermore, to create oneself one has to learn the 'laws' operating in the world: "Wir müssen Physiker sein, um, in jener Sinne, Schöpfer sein zu können" (GS 335). In two very interesting sayings, he says that the one who seeks to determine the rule stands far higher than the one who seeks to determine the exception (AOM 362) and that the rule is far more interesting than the exception (D 442; cf BGE 26). This is a place to pause and think.

It cannot be said that modern scribes have not imbibed much: they know their lists. Whether they still listen is another matter, for listening implies giving heed to a voice that addresses us, the human voice we have so conveniently eliminated. Do we not pirate books that we have not read properly to garner our copious footnotes? If so, we are, in Nietzsche's book, the worst kind of readers (AOM 137).

\section{Opening up}

To listen is to open yourself up, to make space for the other, even if the other is a dead author. While we might regard this as a done job, safely filed under "the otherness of the other" and "Derrida on hospitality", we also persist in a habit of suspicion that selectively closes many cases before they have been heard. ${ }^{26}$ The other, fully theorized but hardly heard, is trotted out to act in the academic game of heroes and villains. But fine phrases do not solve the problem: when does openness become uncritical credulity and healthy scepticism the form of nihilism that Nietzsche deplored?

Nietzsche offers an interesting saying that he probably intended as a useful rule of thumb. You should not be too suspicious of the idea of others in areas that are far removed from you, provided that you have close colleagues who are highly suspicious of your work (AOM 215). This, it seems, may be tweaked slightly to read: Be fairly open to what is far from your experience, ideology and knowledge, and highly suspicious of what which seems close to you. If our scribes heeded this, as they now seldom seem to do, they may distinguish between "the other of my theory" and "the other that upsets my theory".

It is a platitude that wisdom in Israel was part of an 'international' enterprise: Israel "participated in a phenomenon that enveloped the entire Fertile Crescent" (Crenshaw 1998:229) in which it was "to a great extent a receiver and not a donor" (von Rad 1972:9). Israel's openness to foreign material would not be remarkable were it not that exclusivism permeates large parts of the Old Testament. It is precisely here, and not everywhere, that biblical writers took their stance "among the nations". Perhaps the space marked 'wisdom' where humanity stands undifferentiated is always a small and fragile one. Both those who champion inclusion (sometimes narrowly defined) and those who protect identities (sometimes without daring to say 'exclusion') have to reflect at this point ${ }^{27}$. The space is limited and not a seat of power, but it is where we can talk freely across boundaries ${ }^{28}$. 


\section{Mastering Yourself}

Much has been written on the importance of self-discipline in wisdom writings and in Nietzsche, for whom Selbstüberwindung (also Selbstzucht) was always a crucial term. That both listening and openness to others (the two being closely connected) require selfdiscipline is evident. What is seldom noticed is the link between self-discipline and objectivity as a virtue. The ritual slaying of a notion of objectivity that practically nobody holds and that not many ever held is such a popular sport that other avenues remain unexplored, even unseen.

They did catch Nietzsche's eye. His disdain for subjectivity and his regard for the usevalue of objectivity were noted above. The true philosopher goes beyond objectivity, having first passed through it. The stage of receptivity, spreading yourself out to register every faintest movement (BGE 211), is a preparation for saying 'yes' or 'no'. In comparing Nietzsche and Trump, Papazoglou (2016) notes that Nietzsche's perspectivism is misunderstood if it is seen as a blanket validation of the individual's view based solely on personal experience. Such a reading would indeed place Nietzsche on a par with Trump.

But Nietzsche's call is for many perspectives. Even the perverse perspectives spawned by the ascetic ideal help to discipline the mind on its way toward its "einstmaligen "Objektivität". Nietzsche uses the inverted commas to indicate that he does not mean "interesselose Anschauung", which he rightly considers an absurdity. He does mean the ability to command different, sometimes contradictory, perspectives. "Je mehr Augen, verschiedne Augen wir uns für dieselbe Sache einzusetzen wissen, um so vollständiger wird unser 'Begriff' dieser Sache, unsre 'Objektivität' sein." (GM III:12). ${ }^{29}$

Discipline is a bother, self-discipline doubly so. Nietzsche sometimes advocated recklessness - living dangerously (BGE 206, 224). Even more often he advocated the sternest self-discipline, simply because it is so annoyingly useful. ${ }^{30}$ It opens eyes.

\section{Public Speaking}

An Irish bull: To be open to others implies being open to others. What is the point of listening to others if your reply immediately excludes most of them? One of our administrators, an intelligent person but not a scribe, lamented that academics seem intent on restricting their audience. Academic apartheid's sign reads: Members of the herd unwelcome.

Woman Wisdom calls out in public places to a broad public. This does not mean that scribal wisdom was accessible to all in practice. Scribal education, being expensive, was mostly for the upper classes (and males). Moreover, ancient wisdom writings demanded a good bit of mental agility: on the lips of fools who do not understand their implications wise sayings are useless (Prov 26:7). As for those who think they understand Job perfectly... Nevertheless, these considerations do not cancel Woman Wisdom's the selfunderstanding completely. She is in principle directing her call to everyone. It would be better if more had the benefit of her teaching and much better if fewer were fools.

Therefore she resorts to charm, to a language that "combined logic with beauty" (Perdue 2008:5). Having seen how non-elite audiences (some barely literate) react to the mere reading of Job 14, passages from Gilgamesh and scenes from Sophocles's Antigone, I can attest that the magic still works. Though the aesthetic response does not confer understanding, it entices to understanding. The elegance of the presentation invites thought, for who would waste elegance on trifles?

The classic style as described by Thomas and Turner (1994) has as two of its 'enabling conventions' (31) the assumptions that the audience is not a narrow elite (49) and that the 
audience is competent (50-57). If the audience lacks certain specialized items of knowledge, it is by chance, for in principle they can acquire it just as the speaker did (54). The model is the "conversation between equals" (50). Using Foucault's prose as an example, they show how style can create an asymmetrical relationship: the reader has to accept Foucault's superior competence, but has no way of ever sharing it (55f). Though Thomas and Turner explicitly say that the classic style is not the only good style or the best style for all communicative contexts (72-108), one could argue that scribes would do well to adopt it.

Mostly they don't. They generally offer two weirdly contradictory reasons for choosing a style that implies an elite audience and an asymmetrical relationship between writer and reader. On the one hand, scholars "who have gone through graduate training" are professionals, trained in the language of the profession: outsiders should not expect to understand them (Frank, quoted in Jacoby 1994:167). On the other hand, their linguistic contortions are supposed to destabilize (interrupt, subvert) ordinary patterns of thought so as to enable new insights (cf Lasch 1995:178). But if only those trained in the profession and writing in the same jargon can understand them, whose thoughts can be destabilized? If laughter destabilizes thought, 'covfefe' has radically destabilized mine.

Can Lloyd Chetty, our administrator, hear you? Do you want Lloyd Chetty to hear you? If not, why not? If you are addressing Nietzsche's higher people, please call elitism by its name.

\section{The Fear of Yahweh}

If יראת יהוה means merely "trust in and reverence for God" (Perdue 2008:6), one could conclude that in Israel, perhaps at a late stage, wisdom was made entirely dependent on a specific religious faith. This would contradict much of the openness displayed the (earlier?) wisdom literature. This glossing of the term also neutralizes the word 'fear'. In both respects, however, this reading, if adopted simplistically, may be misleading.

Wisdom For any limited being wisdom begins with a recognition of limitations. As noted above, even Nietzsche knew that we can create only within limits. This recognition not only excludes unrealistic (and therefore unwise) aspirations; it also indicates along which lines one could expect positive results. If there is some ultimate power of any sort before which all must inevitably bow, it is wise to have this power on one's side, to cooperate with it. In the faith that Yahweh is this ultimate power, Israel coined the saying that the fear of Yahweh is the beginning of wisdom without thereby denying that there are other powers and that some wisdom flows from 'fearing' them. One can get a long way by cooperating with the king!

If any power is worthy of trust and respect, the element of awe (Ehrfurcht) cannot be excluded completely. Grandly put, the Holy is also the mysterium tremendum; mundanely put, we seek wisdom because folly gets us into trouble. For me most thinking beyond the routine starts with blind panic (and ends when the panic disappears). Nietzsche, who recognized no God and few (if any) equals, did not want fear to disappear ((BGE 201, 226; GM III:14). In the chaotic world that he saw, there was still the Rangordnung: there had to be, else nothing would make any sense. ${ }^{31}$ The 'last man' ( $Z$ prologue 5 ), who invented happiness, banished fear and made all things small, perhaps refers to those who deconstruct hierarchies in the sky and life in cosy, closed coteries on earth. ${ }^{32}$

Academic discourse is often awful and often thinks itself awesome, but there is little of awe in it. Should there be? Here I am a poor guide. Where are you going to begin your thinking? What is the ראשית of your wisdom? 


\section{Scribes that Open Eyes; Scribes with Open Eyes}

Things fall apart as they did in Yeats's time and often before: some will say with Nietzsche: "Der kleine Mensch kehrt ewig wieder" (Z III:13). But is the person who returns petty or merely a פתאים To in whatever wisdom they have is one of the tasks of scribes. If we leave them no wiser, we may at least leave them better informed ${ }^{33}$, with eyes that may see further than ours. This is no time for lamenting fogies or even self-lacerating ones. Perhaps we have messed up, we scribes, but perhaps we have simply overestimated our influence vastly. It is possible that our influence could in future be greater (albeit very indirect) if we opened our eyes to the humanity we have theoretically abolished and saw in this humanity eyes to be opened. That is, if we showed the second face of the scribe rather than the first.

I have "written my tablet" with (I hope) sufficient 'Sumerian' and list wisdom. What does that prove? That I have read all my sources? Think again. Perhaps that I have read Nietzsche slightly more thoroughly than some who quote him, which does not prove that I understand him. If, amid all the posturing, I have indicated that I care for wisdom and the second face of the scribe, the one that humanizes and opens the eyes, and have directed a few gazes in that direction, it has been worth the effort. I present this with deep appreciation to Hendrik Bosman, a scribe with open eyes who opened eyes.

\section{BIBLIOGRAPHY}

Works by Friederich Nietzsche are cited as follows, with roman numerals indicating major parts or chapters and Arabic numerals to sections (not pages):

AOM: Assorted Opinions and Maxims (Vermischte Meinungen und Sprüche, 1879).

BGE: Beyond Good and Evil (Jenseits von Gut und Böse, 1886).

D: Dawn (Morgenröte, 1881).

EH: Ecce Homo, 1908).

GM: The Genealogy of Morals (Zur Genealogie der Moral, 1887).

GS: The Gay Science (Die fröhliche Wissenschaft, 1882).

SE: Schopenhauer as Educator (Schopenhauer als Erzieher, 1874).

TI: Twilight of the Idols (Götzen-Dämmerung, 1889).

WS: The Wanderer and His Shadow (Der Wanderer und sein Schatten, 1880).

Z: Thus Spoke Zarathustra (Also Sprach Zarathustra, 1883-1892).

Quotations in German are from Nietzsches Werke: Klassiker-Ausgabe 9 Auflagen, Stuttgart: Alfred Kröner, 1921).

Ackermann, Denise M. 2014. Surprised by the Man on the Borrowed Donkey. Cape Town: Lux Verbi.

Andreas-Salome, Lou. 1894. Nietzsche in seinen Werken. Dresden: Carl Reiszner.

Appel, Frederick. 1996. The Objective Viewpoint: A Nietzschean Account. History of Philosophy Quarterly 13 (no.1):483-502.

Atlas, James. 1990. Battle of the Books. New York/London: Norton.

Bamford, Rebecca. 2007. Nietzsche and Ubuntu. South African Journal of Philosophy, 85-97. 
Beaulieu, Paul-Allain. 2007. The Social and Intellectual Setting of Babylonian Wisdom Literature. In RJ Clifford (ed.), Wisdom Literature in Mesopotamia and Israel, Pages 3-19. Leiden/Boston: Brill.

Berry, Jessica M. 2015. Is Nietzsche a Virtue Ethicist? Journal of Value Inquiry 49 (no. 2): 369-386.

Bhabha, Homi. \& Atwell, David. 1993. Interview with Homi Bhabha. Current Writing 5 (no. 3):100-113.

Brenner, Athalya. 1993. Proverbs 1-9: An F Voice? In A Brenner and F van Dijk-Hemmes, On Gendering Texts: Female and Male Voices in the Hebrew Bible. Pages 113-130. Brill: Leiden.

Brinton, Crane. 1940. The National Socialists' Use of Nietzsche. Journal of the History of Ideas 1 (no.2, April):131-150.

Camp, Claudia V. 1990. The Female Sage in Ancient Israel and in the Biblical Wisdom Literature. In JG Gammie and LG Perdue (eds.), The Sage in Israel and the Ancient Near East. Pages 185-203. Winona Lake: Eisenbrauns.

Carr, David M. 2005. Writing on the Tablets of the Heart. Oxford: OUP.

Cohen, Tom. 1995. The 'Geneaologies' of Pragmatism. In S Mailloux (ed.), Rhetoric, Sophistry, Pragmatism. Pages 94-108. Cambridge: Cambridge University Press.

Cornell, Drucilla \& Stephen D. Seely. 2016. Seven Theses on Trump, Critical Legal Thinking .Accessed 16 July 2017.

Crenshaw, James L. 1998. Old Testament Wisdom: An Introduction (Revised edition). Louisville: Westminster John Knox.

Fish, Stanley E. 1989. Doing What Comes Naturally. Durham/London: Duke University Press.

Fish, Stanley E. 2016. Don't Blame Nietzsche for Donald Trump, Foreign Policy 9 August 2016. Available at: foreignpolicy.com/2016/08/09/don't-blame-nietzsche-fordonald-trump/. Accessed 6 August 2016.

Gemes, Ken. 2001. Postmodernism's Use and Abuse of Nietzsche. Philosophy and Phenomenological Research, 337-360.

Girard, René. 1989. Theory and its Terrors. In TM Kavanagh (ed.) The Limits of Theory. Pages 225-253. Stanford: Stanford University Press.

Ginzburg, Carlo. 1999. History, Rhetoric and Proof. Hanover/London: University Press of New England.

Golomb, Jacob. 2017. The Case of Nietzsche against Trump, The Critique, 15 January 2017. Available at: www:thecritique.com/articles/nietzsche-against-trump/. Accessed 6 August 2017.

Graff, Gerald. 1989. "The Future of Theory in the Teaching of Literature", in R Cohen (ed.), The Future of Literary Theory. Pages 250-267. New York/London: Routledge.

Hamilton, Richard F. 1996. The Social Misconstruction of Reality. New Haven/London: Yale University Press.

Harris, Rivkah. 1990. The Female "Sage" in Mesopotamian Literature (with an Appendix on Egypt). In JG Gammie \& LG Perdue (eds.), The Sage in Israel and the Ancient Near East. Pages 3-17. Winona Lake: Eisenbrauns.

Harris, William V. 1989. Ancient Literacy. Cambridge, MASS: Harvard University Press. 
Hollingdale, RJ. 1973. Commentary. In Friedrich Nietzsche, Beyond Good and Evil (translated by RJ Hollingdale). Pages 205-238. Harmondsworth: Penguin.

Jacoby, Russell. 1994. Dogmatic Wisdom. New York: Doubleday.

Lash, Christopher. 1995. The Revolt of the Elites and the Betrayal of Democracy. New York: Norton.

Lather, Patti. 1996. "Methodology as Subversive Repetition: Practices Toward a Feminist Double Science." Unpublished paper delivered at the annual meeting of the American Educational Research Association, New York (no page numbers).

Leiter, Brian. 2014. The Recurring Myth about Nietzsche and Fascism, Huffington Post 6 August 2014. Available at: www.huffington post.com/brian-leiterNietzsche-andfascismb_5458843.html. Accessed 1 August 2017.

Leiter, Brian. 2015. Nietzsche's Moral and Political Philosophy, The Stanford Encyclopedia of Philosophy (winter 2015 edition), EN Zalta (ed.). Available at: https://plato.stanford.edu/archives/win2015/nietzsche-moral-political/>. Accessed 18 July 2017.

Nehemas, Alexander. 1999. Nietzsche and 'Hitler'. Southern Journal of Philosophy 37 Supp, 1-15.

Papazoglou, Alexis. 2016. The Post-Truth Era is Just What Nietzsche Predicted, The Conversation, 14 December 2016. Available at:

Theconversation.com/the-post-truth-era-is-just-what-nietzsche-predicted-69093. Accessed 18 December 2016.

Perdue, Leo G. 2008. The Sword and the Stylus: An Introduction to Wisdom in the Age of Empires. Grand Rapids: Eerdmans.

Schacht, Richard 2016. Letter to the editor, New York Times 13 July 2016. Available at: https//:www.nytimes.com/2016/07/13/opinion/donald-trump-and-nietzsche.html. Accessed 1 August 2017.

Sneed, Mark. 1994. Wisdom and Class: A Review and Critique, JAAR 62, 651-672.5 Sneed, Mark. 2011. Is the "Wisdom Tradition" a Tradition? CBQ 73, 50-71.

St Pierre, Elizabeth A. 1996. Methodology in the Fold and the Irruption of Transgressive Data. Unpublished paper delivered at the annual meeting of the American Educational Research Association, New York (no page numbers).

Thomas, Francis-Noël \& Turner, Mark. 1994. Clear and Simple as the Truth: Writing Classic Prose. Princeton: Princeton University Press.

Van der Toorn, Karel. 2007a. Why Wisdom Became a Secret: On Wisdom as a Written Genre. In RJ Clifford (ed.), Wisdom Literature in Mesopotamia and Israel.

Pages 21-29. Leiden/Boston: Brill.

Van der Toorn, Karel. 2007b. Scribal Culture and the Making of the Hebrew Bible. Cambridge, MASS, Harvard University Press.

Von Rad, Gerhard. 1972. Wisdom in Israel (translated by JD Martin). London: SCM.

Walter, Eric. 2017. Nietzsche, our Contemporary, Philosophy Today 121

August/September 2017. Available at:

https//:philosophynow.org/issues/93/Nietzsche_our_contemporary/. Accessed 10 August 2017. 


\section{Endnotes}

1 Here is a selection: Stanley Fish (2016), Drucilla Cornell and Stephen Seely (2016), Alexis Papazoglou (2016), Eric Walter (2017), Richard Schacht (2016), Jacob Golomb (2017). The last four are philosophers, the last two eminent Nietzsche scholars. Earlier, another Nietzsche scholar, Brian Leiter (2014), defended Nietzsche against the charge of fascism - again. He quotes, predictably, BGE 251 to show Nietzsche's high regard for Jews, neglecting to add BGE 195 and GM I:7 (highly critical). Quoting Nietzsche can be like prooftexting! Crane Brinton (1940) had already, at a crucial time, listed the many ambiguous (if not outright contradictory) strands in Nietzsche that bear on fascism. More recently Alexander Nehemas has accused Nietzsche scholars of skirting the issue of Nietzsche's attitude to the 'evil hero', whom he calls 'Hitler' (to distinguish him from the singular figure) (1999:1). He concludes that 'Hitler' does conform to Nietzsche's criteria for nobility (15). Nietzsche's philosophy "refuses to reject the evil hero unconditionally", but this is because of Nietzsche's complete rejection of morality, which is itself a form of the dogmatism Nietzsche rejected (16). If Nietzsche's own view had a moral basis (14f), we may affirm Nietzsche while rejecting certain of his conclusions (15).

2 Why is wisdom personified as a woman in a patriarchal culture? The common view that Woman Wisdom is a distant shadow of a goddess of wisdom does not answer this question. Probably Perdue (2008:7) is right to see in her "an intellectual eros or the alluring incarnation of divine Wisdom ... an entrancing and intelligent woman teacher". In short, the (male) sages saw wisdom as a woman because wisdom is desirable.

3 But not never. See Harris (1990) on female scribes and sages in Mesopotamia and Egypt, and Camp (1990) and Brenner (1993) on them in Israel. Did these women, being a small minority, share the scribal ethos? Though, as Sneed (2011:62f) points out, scribes necessarily had a hand in all biblical texts.

See Beaulieu (2007:10-17) for part of this convoluted history.

6 Mark Sneed has questioned the assumption that Israelite scribes all belonged to the upper class, pointing out that the class analysis is shaky (see Sneed 1994). He pointedly refers to academics to indicate that (social) status does not imply economic or political power (658). Elsewhere (Sneed 2011:61f) he quotes Saldarini's view that the word 'scribe' could refer to roles ranging from (in modern terms) "typist to cabinet officer"

7 See Harris (1989:5f) for the early use of these terms, which soon meant both "unable to read and write" and "lacking in culture".

8 While modifying the nationalism of his early lectures Über die Zukunft unserer Bildungsanstalten, his attitude remained unchanged (cf TI VII:5-7). Scholars are not higher people and by instinct follow the herd (GS 373).

9 Nietzsche is often 'appropriated' without mention of his elitism. Bamford (2007), searching for links between Nietzsche and Ubuntu, uses mainly one enigmatic passage from Zarathustra and concepts such as 'authenticity' that Nietzsche himself never uses - no word about elitism or "Jede Gemeinschaft macht ... 'gemein"' (BGE 284; cf GM III:18). Berry (2015) is far more plausible when she says that we should assume that Nietzsche means what he says (often and clearly) and "not to supply him with theories that he himself does not attempt to develop" (283f). As she adds, this does not mean always taking him literally.

Obviously this is not fully possible; but Nietzsche tacitly admits that it is not fully impossible either. The scholar who works in this way is like extremely precious instruments, but belongs "in the hand of one who is mightier" (BGE 211). Could some of our students be among the mightier ones?

11 English translations usually use 'noble' where Nietzsche has 'vornehm'. Nietzsche's obsession with being vornehm grated even his friends Rohde and Overbeck. For their comments on it, see Ginzburg (1999:28f).

Sande Cohen (quoted in Jacoby 1994:171) says that clarity leads to 'intellectual evasion': academic writing must "refuse to convince a reader by its cadence or even rightness". "An emerging body of literature addresses the politics and ethics of accessibility and questions the demand for a not so innocent clear speech that is often powerfully overcoded and leveled to a violent and deadening transparency" (St Pierre 1996). Just as, in the 1930s, a substantial body of literature addressed the "not so innocent presence of Jews in Europe"? Patti Lather (1996) quotes Deborah Britzman's hope that "educational research will become unintelligible to itself" and adds: "Britzman's statement situates unintelligibility as an ethical imperative and political intervention in terms of disrupting the ways we make sense." Even those whose writings are impenetrable are usually lucid in interviews - perhaps to their disadvantage! The long footnote to this sentence (on the same page) is, if anything, even more obscure - or absurd. For similar pronouncements, see Girard (1989:238ff); Graff (1989:257). 
17 Herrnstein Smith (quoted in Atlas 1990:17) speaks of "cross-citing and mutually puffing ... articles" referring to journalists. Not to academics?

18 For instance, in Battle of the Books (1990), James Atlas, a journalist, surveys the American academic scene (Humanities) in a well-informed and balanced way. He deplores the jargon, insularity and self-praise of some academics, but he is also suspicious of journalists "who put down academics" and of academic critics of academia with an axe to grind (79).

19 This may not worry Fish. In the same volume (1989:342-355) he argues, against the popular academic view, that 'anti-foundationalist' theory has no practical impact: "practice has nothing to do with theory" (355). This he has repeated recently (Fish 2017): postmodern theory advocates no course of action. In spite of theory, "at any given time we always know what is right and wrong, true and false", but only as a particular perspective, one with no special validity. We have to live with this battlefield of "different and opposing facts". Trump?

20 An example of biblical scholarship: Just as allegorical interpretation should be used for allegories, not other texts, redactional criticism should be used for edited texts. The assumption that all biblical texts have undergone a process of redaction (to the same extent) should at least be examined.

21 Clark (1990:63-93) argues that Nietzsche's position is contradictory in Über Wahrheit und Lüge im aussermoralische Sinne (from which his followers love to quote but that Nietzsche himself did not publish), but that Nietzsche saw the problem and abandoned his earlier position (though there are traces even in the "middle period"). Leiter (2015) says the view of Nietzsche as "a global anti-realist" who rejects all truth claims has now "been widely discredited".

22 See the play on the various meanings of Versuch and Versuchung in BGE 42.

23 See his remarks on modern exegetes who try to neutralize the tension between their own view of reality and that of the sages "by means of some sort of criticism", without ever subjecting their own views to critical scrutiny (von Rad 1972:301). In brief, they analyse the texts without listening to them.

24 Compare also: "Experience ... teaches that you can never be certain. You must always remain open to new experiences" (1972:106); "[T] he sense of a sentence was never completely fixed; any attempt to understand it was always a flexible one" (33). What is discovered includes contradictions (199), for "All truth is inscrutable; only to the uncritical man does it appear ... clear and unequivocal" (297). Is this very far from Nietzsche?

25 On this, see Leiter (2015), arguing against, for instance, Schacht's view.

26 When an article announces that it intends to 'interrogate' $\mathrm{X}$, we may be sure that at the close $\mathrm{X}$ will come forward, somewhat worse for wear, to confess its crimes at the show trial. Have some academics stopped listening to themselves?

27 Lash (1995:17) notes how the slogan 'diversity' has come to mean its opposite, since "rival minorities take shelter behind a set of beliefs impervious to rational discussion", each barricaded behind "its own dogma".

28 "Civic life requires settings in which people meet as equals, without regard to race, class or national origin" (Lasch 1995:117).

29 For a good account of Nietzsche's view on objectivity, see Appel (1996).

30 Thus, while rejecting the ascetic ideal, he advocates a version of it for philosophers (GM III:8, 9).

31 Here I interpret. Though Nietzsche was an atheist and had been disappointed in his heroes Wagner and Schopenhauer, he could not imagine a life in which reverence played no role (cf BGE 263). Hence his insistence on the order of rank and on "the pathos of distance" (BGE 257; GM I:2, III:18), a phrase that deserves attention. Pure equality abolished that except if there is a God (cf BGE 219). The pathos of distance is the gap left by the absence of God.

32 In a general critique of the postmodern use of Nietzsche that focuses particularly on the issue of the subject, Gemes (2001:357) concludes that the decentred subject of postmodernity corresponds to Nietzsche's last man, not to the overman.

33 When a judge told FE Smith that his long explanation "leaves me [the judge] none the wiser", Smith replied: "I know, your honour, but it does leave you better informed." 